\title{
"Crying whenever Monday comes": Older Unmarried Women in the Netherlands and the Game of Comparison, 1955-1980
}

Citation for published version (APA):

Bijsterveld, K. T., Horstman, K., \& Mesman, J. (2000). "Crying whenever Monday comes": Older Unmarried Women in the Netherlands and the Game of Comparison, 1955-1980. Journal of Family History, 25(2), 221-234. https://doi.org/10.1177/036319900002500207

Document status and date:

Published: 01/01/2000

DOI:

10.1177/036319900002500207

Document Version:

Publisher's PDF, also known as Version of record

Document license:

Taverne

Please check the document version of this publication:

- A submitted manuscript is the version of the article upon submission and before peer-review. There can be important differences between the submitted version and the official published version of record.

People interested in the research are advised to contact the author for the final version of the publication, or visit the DOI to the publisher's website.

- The final author version and the galley proof are versions of the publication after peer review.

- The final published version features the final layout of the paper including the volume, issue and page numbers.

Link to publication

\footnotetext{
General rights rights.

- You may freely distribute the URL identifying the publication in the public portal. please follow below link for the End User Agreement:

www.umlib.nl/taverne-license

Take down policy

If you believe that this document breaches copyright please contact us at:

repository@maastrichtuniversity.nl

providing details and we will investigate your claim.
}

Copyright and moral rights for the publications made accessible in the public portal are retained by the authors and/or other copyright owners and it is a condition of accessing publications that users recognise and abide by the legal requirements associated with these

- Users may download and print one copy of any publication from the public portal for the purpose of private study or research.

- You may not further distribute the material or use it for any profit-making activity or commercial gain

If the publication is distributed under the terms of Article $25 \mathrm{fa}$ of the Dutch Copyright Act, indicated by the "Taverne" license above, 


\title{
“CRYING WHENEVER MONDAY COMES": OLDER UNMARRIED WOMEN IN THE NETHERLANDS AND THE GAME OF COMPARISON, 1955-1980
}

\author{
Ka in Bijsterveld \\ Klasien Horstman \\ Jessica Mesman
}

\begin{abstract}
The Dutch Women's Action Committee for Early State Pensions advocated the reduction of the retirement age for unmarried women. In doing this, the committee brought forward an image of older unmarried women that was rather different from the self-images the older unmarried women presented in letters and questionnaires sent to the committee. And the image presented by the committee was again different from the image of older unmarried women that emerged in the parliamentary debate. Such a variation in images and self-images is related to the legal nature of the welfare state and the consequent comparison between social categories.
\end{abstract}

In 1969, a sixty-one-year-old unmarried woman wrote a letter describing her day-today life. From an early age she had worked in a workshop making flags. She was far from happy there, as she had very little in common with her colleagues, girls aged between sixteen and twenty. There was an unbridgeable gap between her and the others. "There's noise every day. These hippies want the radio on all day." In her view, older single women no longer counted, even though they paid the highest taxes. She owned a time-consuming house but could not afford to hire someone to do her cleaning. It was easier for men like her brothers: their dinner was ready when they got home and they could just sit down and read the paper afterward. She herself was too tired to

Karin Bijsterveld is a historian and assistant professor in the technology and society studies department, University of Maastricht, the Netherlands. She has published on the history of academic and political discourse concerning elderly and graying populations, including Geen kwestie van leeftijd. Verzorgingsstaat, wetenschap en discussies rond ouderen in Nederland, 1945-1982 (1996). A summary in English ("No Matter of Age: Welfare State, Science and Debates about the Elderly in the Netherlands, 1945-1982") is available. Klasien Horstman is assistant professor in the Department of Health Ethics and Philosophy, University of Maastricht, the Netherlands. She has been trained as a historical sociologist and is author of a book on the history of insurance medicine. A recent publication is "The Chemical Analysis of Urine for Life Insurance: The Construction of Reliability," in Science, Technology \& Human Values (1997). Jessica Mesman is director of studies of the international master's program European Studies on Society, Science and Technology in the Faculty of Arts and Culture, University of Maastricht, the Netherlands. She is the author of "Neonatal Food and the Politics of Theory: Some Questions of Method," Social Studies of Science (1996). 
go to church on Sundays and knew "many others who are miserable, crying whenever Monday comes."1

The letter from this tired woman was addressed to the Dutch Women's Action Committee for Early State Pensions (Vrouwen-actiecomité voor Vervroegd Staatspensioen), founded in 1962, which was one of the organizations advocating a reduction of the retirement age for unmarried women within the framework of the General Old Age Pensions Act (Algemene Ouderdomswet). This issue had been on the parliamentary agenda ever since the introduction of the pensions bill in 1955 and would regularly return to it until the early 1980s. Meanwhile, the committee received a large number of letters and questionnaires - the committee had organized a poll—in which older unmarried women described their lives. These women gave succinct descriptions of their lives, put forward arguments for a lower pensionable age, and defined their self-images by evaluating their own situations and behaviors. ${ }^{2}$

In most cases, these self-images were similar to that presented in the letter of the sixty-one-year-old woman cited above. However, these self-images were rather different from the image of older unmarried women that was projected by the committee. And the image presented by the committee was again different from the image of older unmarried women that emerged in the parliamentary debates. Such differences are at the core of this article. By examining the self-image of a group of older unmarried women, the image projected by representatives of this group, and the development of the image of this category in Parliament, we will try to gain insight into the various experiences of and opinions about some of the older unmarried women in the Netherlands after the Second World War. At the same time, we will try to find out how this variation in images and self-images came about. In the following, we will show that the differences between the public image and the self-images of older unmarried women were not coincidental but were connected with the way in which categories of people were compared in the context of the welfare state.

As David Troyansky has made clear, people construct their biographies in specific ways when claiming state provisions on the basis of legal rights. In general, biographies and self-images in letters cannot be separated from the goals and readers the writers have in mind. In this way, the private and public may be interconnected. ${ }^{3}$ Processes like these were also important with respect to the older women under study. But first of all, we will give them the floor.

\section{WORKED LONG ENOUGH: A DOUBLE JOB AND WORN OUT}

During its existence, the Women's Action Committee for Early State Pensions received a large number of descriptions of the lives of older unmarried women, ${ }^{4}$ which arrived both in the form of letters and in that of answers to a questionnaire distributed by the committee to more than a thousand women in $1966 .{ }^{5}$

Thirty-nine of the letters and postcards we found in the archives were relevant to our investigation. ${ }^{6}$ They contain descriptions of the lives of women of whom it was certain or practically certain that they were not married and that they were at least forty. ${ }^{7}$ As far as we know, all these letters and postcards were mailed between 1968 and 1975. Of the questionnaires that have been preserved, 214 were relevant to our investigation. ${ }^{8}$ These were questionnaires completed by unmarried women age forty and older, which not only contained answers to questions about personal details, occupation, marital status, 
health, housing, opinion on lower pensionable age, and so on, but further remarks as well. Just like the relevant letters, these remarks usually combined expressions of support, descriptions of the women's lives, and arguments for a lower pensionable age.

We examined the remarks and the letters for instances of the women's self-images by using a code list. ${ }^{9}$ A letter or a remark in a questionnaire was often allotted more than one code; this resulted in a total of 367 allotted codes. It should be noted, however, that neither the women who wrote the letters nor those who took part in the poll were representative of the category of older unmarried women as a whole. The letters were often reactions to publicity about the committee or to activities organized by the committee. With the exception of one letter, all letters were written by women who sympathized with the aims of the committee, and most of them lived in the western and central parts of the country, as did most of those who completed the questionnaire. The questionnaires were distributed upon request or were passed on from one person to another and probably remained within certain circles. However, both the women who wrote the letters and those who completed the questionnaire did belong to various occupational groups.

The central element in the self-images of the women who described their lives was the demanding nature of the combination of a paid job and domestic labor. Of all the remarks that we distinguished, this was the type of remark that was made most frequently. A sixty-two-year-old woman who worked in the linen room of an old people's home described her demanding job and added, "And as soon as you get home, you can start all over again.” Married women who wanted a job outside the home, another woman wrote, would soon think better of it "if they had to rush from home to work and vice versa all the time, like we did all those years." If women were to receive an old-age pension at the age of sixty, a sixty-one-year-old secretary said, "I would give up work straight away, because having a job plus doing your own housework is simply too much." One woman even went to the length of giving a full account of her days, which were filled with her job, shopping, cooking, washing, and tidying up, until she was exhausted and went to bed relatively early. In addition to this, some women also had to care for one or both of their parents, which meant that their double jobs became triple jobs, as it were.

However, the women complained not only about the large number of responsibilities that they had but also about the demanding nature of their jobs, about their physical condition, and about their health. "Although I take great pleasure in my work," an employee of a foundation for efficient housing wrote, "I do get very tired. I do not want to quit my 'job', but I think that I will not be able to continue until I am 65." A fiftythree-year-old bookkeeper, on the other hand, had had enough of her job at the office. "The idea of having to stay at this office for another 111/2 years is awful. And I wonder how many others are in the same situation." "So you must be one of the very strongest," a sixty-year-old needlework teacher concluded, "if you are to continue this work until you are 65." Women frequently indicated that they could not bear the pressures of this busy existence any more. A switchboard operator's answer to the question in the questionnaire about her opinion on the reduction of the pensionable age was, "As soon as possible! I am exhausted already!" Furthermore, the letters and the answers to the questionnaire contained many descriptions of health problems: from back complaints to high blood pressure, from nervousness to neurological disorders.

Apart from this, many women simply thought that they had worked long enough. "I think that it is quite enough for a woman to have worked for 46 years," somebody 
working in the clothing industry wrote. A teacher remarked that "those who are over sixty shouldn't be teaching any more." It was only fair, a fifty-nine-year-old packer thought, that women who had worked all their lives were able "to take things a bit easier" at sixty. In that case, some women dreamed aloud, they would at least have some time left to enjoy life.

The burden of everyday life was the most important aspect of the picture that these women drew of their lives. Almost two-thirds of the coded remarks (219 out of 367) and almost three-quarters of the letters and questionnaires that were analyzed (189 out of 253) contained references to the pressures that were experienced, such as a double workload, a demanding job, a bad physical condition, bad health, or a feeling of having worked long enough. We were unable to detect a relationship between these aspects and the women's occupations. The seamstress and the accountant, the home helper and the laboratory assistant, the ticket inspector and the deputy headmaster were unanimous in their descriptions of a taxing existence.

In addition to this, the women also indicated that they thought that they were being treated unfairly compared to other groups of individuals, a matter that was to be central to the campaign of the Women's Action Committee and the parliamentary debates and to which we will return later. More than one-quarter of the women (70 out of 253) referred to others who were better off in their eyes. Nevertheless, the number of remarks in this vein was considerably smaller than the number of complaints about the hard life that these women led. And when they compared their situations to those of others, the comparisons involved different groups of people.

For instance, older unmarried women felt that they were treated unfairly compared to men. Furthermore, they cast envious looks at widows. One of the women thought that a reduction of the retirement age was absolutely necessary "because a healthy widow aged 40 or over, without children, is also pensioned off early." This comparison added to the feeling of injustice. "It seems rather unfair that a widow with grown-up children, who supply her with an income, does get a pension," a sixty-one-year-old woman wrote. Another woman was hoping for better times "because many acquaintances of mine who are widows without children have enjoyed a widow's pension for years, while we, unmarried women, always have to struggle along." A sixty-two-yearold domestic, who had cared for her mother for years, had a rheumatic sister, and was in bad health herself, contrasted her life with that of a widow. She had to leave home at seven o'clock in the morning. "A widow is still sound asleep at that hour." 10

Still, from the point of view of most older unmarried women, it was not this "envy" of widows that made their lives difficult. Most of them described themselves as tired and overburdened. That was the main theme of the letters and the remarks in the questionnaires. This self-image was not the main theme chosen by the Women's Action Committee, however.

\section{"WIDOWS ARE NOT MADE OF CAKE-UNMARRIED WOMEN ARE NOT MADE OF STEEL"}

The committee's main theme was expressed in, for instance, the slogans carried by the committee during one of its protest marches. An article in the Christian-Socialist weekly Patrimonium about one of these marches contained the following passage: 
I saw them on television, carrying that wonderful slogan, which sounds like a protest song: "Widows are not made of cake-unmarried women are not made of steel." "Cake," that is just the right word. Cake! Sweet, delectable, tempting, delicate, perishable. A range of adjectives that will never be associated with old, cold, imperishable steel. . . . A psychoanalyst would deduce quite a lot from this antithesis about the thoughts and emotions of those who invented it. And probably with good reason, because there seem to be worlds of indignation behind it. ${ }^{11}$

The writer of this article could hardly have done the committee a greater service, for the comparison with widows was central to the committee's plea for a lower pensionable age. The committee was set up as a reaction to the introduction of the revised General Widows and Orphans Act (Algemene Weduwen- en Wezenwet) in 1961. Among other things, this revision meant that widows without children would, from then on, receive pensions if they were forty or older at the time they were widowed. The age limit used to be fifty. The committee, founded by a former dressmaker and a former secretary, considered this highly unfair. ${ }^{12}$ The members of the committee saw no reason why childless widows should enjoy pensions from such an early age, while unmarried women had to work until they were sixty-five. In almost all of their pamphlets, letters, comments, and marches, they returned to this issue, often not very tactfully. It was repeatedly stated that this inequality was the main reason why unmarried women felt discriminated against. Widows received pensions twenty-five years earlier than unmarried women did, "in spite of the fact that many widows are left well provided for, and sometimes even very well provided for ... while an unmarried woman has to fend for herself all her life." ${ }^{13}$ According to the committee, one of the arguments put forward by the Pensions Board in connection with the revision of the General Widows and Orphans Act was that the Dutch people would not like it if widows were forced to work until the age of sixty-five. Could the people, then, "stay dry-eyed when unmarried and divorced women had to work until they reached 65 ?"14

As a reaction to the revision of the General Widows and Orphans Act that had caused their indignation, the members of the committee demanded a reduction of the age at which state pensions were payable for unmarried women to sixty. ${ }^{15}$ Because they usually also included divorced women and sometimes also widows without widows' pensions, the committee not only received letters from unmarried women but also quite a large amount of mail from divorced women and several reactions from widows. Nevertheless, the committee's campaign centered on women who had never married, the category that was also at the center of the parliamentary debate.

The committee not only repeatedly called attention to the privileged position of widows but also to that of married women. Within the framework of the General Old Age Pensions Act, married women received old-age pensions indirectly because married men were entitled to married persons' pensions from the age of sixty-five, irrespective of their wives' ages. This nettled the campaigning women because it meant that, without ever having paid any contributions, most married women received oldage pensions before reaching the age of sixty-five, as men usually married younger women in the Netherlands. ${ }^{16}$

Although the comparison between the treatment of older unmarried women and that of widows and married women was definitely central to its campaign, the committee had more strings to its bow. For instance, many of the committee's publications contained references to the situation in countries where, unlike in the Netherlands, 
women were allowed to retire earlier than men. The committee indicated that this was also the case in the pension schemes of certain companies and branches of industry and in the army. Furthermore, the members of the committee declared that they were mainly speaking on behalf of working-class women. University-trained women could afford domestic help, but working-class women had to do their own housework, and this work was important to them. Women with an academic background considered a paid job as an opportunity for self-development, whereas women in workshops and factories mainly worked to earn a living. According to the committee, this was the reason why the latter group especially yearned for a reduction of the pensionable age. ${ }^{17}$ Occasionally, the situation of unmarried women was compared to that of unmarried men. The committee held the view that some of the grievances, like high contributions and taxes, also applied to unmarried men. But an unmarried man could still marry at a later age so that he had not paid his Widows Act contributions for nothing. ${ }^{18}$ The committee apparently assumed that unmarried women, unlike unmarried men, had little chance of marrying at a later age.

Just like the women had done in the descriptions of their lives, the members of the committee described with pathos the pressures of the double and sometimes triple demands made on the women whose cause they championed. But while the laments in the women's descriptions of their lives usually stood alone, the committee almost always linked the complaints to comparisons. For instance, in connection with complaints about double demands made on unmarried women, the committee remarked that in its opinion women physically aged sooner than men. Women should, therefore, be allowed to "take things a bit easier" during and after menopause.$^{19}$ The long days of unmarried women did not automatically lead to illness or disablement at a later age, which meant that a disablement pension would not solve the problem, but they did lead to fatigue. It was, therefore, wrong to look upon older women workers as "whiners" because life was really more difficult for them than for others. ${ }^{20}$

While the older unmarried women who described their lives in letters and questionnaires drew a picture of themselves as tired and overburdened, the committee mainly portrayed older unmarried women as treated unfairly and as a group discriminated against compared to others. This discrepancy can be explained by placing the committee's line of approach in the context of the welfare state.

In various publications, sociologist C.J.M. Schuyt has drawn attention to the consequences of the so-called legal nature of the welfare state. The term "legal nature" refers to the distribution of welfare provisions among the population in the welfare state on the basis of rights laid down in laws. ${ }^{21}$ However, due to the precedents that are established and the demand for equality before the law, these formal rights cause individuals to continually compare their achievements with those of others to detect "unfair" differences and to make demands. According to Schuyt, "social comparison" is a crucial factor in the formulation and defense of these demands. Individuals may point out that they do share certain characteristics with other individuals while they do not share certain rights and that they should (also) be entitled to certain provisions. The discrepancy between the self-images of the older unmarried women who wrote to the committee and the image of this group that was projected by the committee is, therefore, no coincidence. It was the legal nature of the welfare state that made it necessary for the committee to strengthen the demand for a lower pensionable age by comparing older unmarried women with other social categories, thus underlining unfair treatment rather than drawing attention to the difficulty of their lives. In addition to this, the 
"game of comparison" added to the discrepancy between the image created by the committee and the image of older unmarried women that emerged in the parliamentary debate (discussed below). Comparisons also brought about a shift in the parliamentary image. Each time, a different aspect of the lives of older unmarried women was highlighted in these comparisons. This would eventually not do the cause of unmarried women any good.

\section{WHAT DO YOU MEAN, TIRED?- A SHIFT IN THE IMAGE}

The issue of the pensionable age of unmarried women had been on the parliamentary agenda since 1955 . $^{22}$ Just like the Women's Action Committee, members of Parliament frequently used comparisons when they raised the subject of a reduction of the retirement age for unmarried women to show that this category was treated unfairly. These comparisons involved women in occupational pension schemes and women in other countries as well as other groups of individuals. It was, for instance, indicated that it was just as difficult for unmarried women who had cared for their relatives for years to find jobs outside the home at a later age as it was for widows and divorced women. Another argument for a reduction of the retirement age was that unmarried women should be compensated for paying Widows Act contributions all their working lives, while they would never qualify for widows' pensions. It was sometimes mentioned that life was hard for many older women - it was said that work was an effort for them-but such remarks were usually followed by a comparison. It was assumed that it became increasingly difficult for single women to meet the double demands that were made on them as they grew older. In addition, the differences between women and men were underlined; members of Parliament pointed out that women were more at risk of becoming disabled than men and that job opportunities were more restricted for them. ${ }^{23}$

This comparative approach resembled that of the Women's Action Committee in which unmarried women were compared with widows, married women, and others. Other interest groups representing unmarried women also based their arguments on comparisons. For instance, the Federation of Associations for the Furtherance of Nursing and Other Sections of the Public Health Sector (Federatie van Verenigingen die de Verpleging en andere onderdelen van de Gezondheidszorg bevorderen) explained to the minister that a relatively large proportion of unmarried women had occupations in which interpersonal relations played an important part. Such occupations could become too taxing at an older age. ${ }^{24}$

In this way, groups of individuals were compared from different angles, and different social categories, which were sometimes more and sometimes less precisely defined, passed in review. To expose the unfair treatment of unmarried women, women were compared to men, unmarried women to widows, unmarried women to married women, and older unmarried women to widows and divorced women. By emphasizing the differences with regard to certain groups, an image was created of older unmarried women as a separate category. By at the same time stressing the similarities with other groups, which were already receiving special treatment, the image of older unmarried women was placed on an equal footing with that of these other groups.

But these comparisons in particular were to be attacked by members of the government and their advisory bodies. Similarities were denied, comparisons were altered, 
differences were reasoned away, and new comparisons were deployed. As early as 1955, it was, for instance, denied that the pensionable age for women was sixty in a large part of the private sector. ${ }^{25}$ However, the comparisons that had been used were criticized most systematically in a report published by the Social Economic Council (Sociaal-Economische Raad) in $1966 .^{26}$

With regard to comparisons with the situation in other countries and in private enterprise, the Social Economic Council argued that it was indeed true that the pensionable age for women was often lower than that for men but that this involved a difference in gender and not in marital status. The argument that unmarried women with jobs usually also did their own housekeeping and that this became more of a burden as they grew older failed to impress the council. The council was of the opinion that, if it was true, this would lead to a higher disability and/or disease rate, which, according to the council, was not the case.

The Social Economic Council also refused to be mollified by the alleged discrimination against older unmarried women compared to widows of the same age. The majority of the council held the view that the argument pertaining to widows was sociopsychological in nature and could not be supported or negated quantitatively. Moreover, those who were using the argument did not realize that it was more difficult for widows to find jobs, because they had concentrated on domestic activities during their marriages, than for women who had always had jobs outside the home. The argument that unmarried women, in fact, had double jobs was not valid either, according to the council, because it also applied to married women who went out to work and to unmarried men living alone. In view of their income position, it was easier for married women to leave employment if they could no longer meet the double demands made on them than for unmarried women, but this did not provide the legal foundation for a measure that would only apply to unmarried women. Besides, there was also a relatively large group of unmarried women who did not go out to work and who, therefore, did not have a double workload. Denial and alteration of similarities and differences resulted in a shift in the content of the image of older unmarried women not only in the Social Economic Council but also in Parliament, where the data and alternative comparisons provided by the council were hardly disputed. The opinion that older unmarried women were a disadvantaged group was not shared by the Social Economic Council, which consequently did not support a reduction of the retirement age for unmarried women. A solution by means of supplementary pensions was considered more suitable, and for unmarried women in employment, the Sickness Benefits Act (Ziektewet) and the Disablement Insurance Act (Wet op de Arbeidsongeschiktheid) offered better arrangements than the General Old Age Pensions Act. However, the council did ask for an investigation into the living conditions and social position of unmarried people and of unmarried women in particular.

\section{OLDER UNMARRIED WOMEN OUT OF THE PICTURE}

The most far-reaching changes in the parliamentary debate occurred in the 1970s. In the course of this decade, there was not just a shift in the image of older unmarried women; as a category, they disappeared altogether.

In the report published by the Social Economic Council in 1966, it had already been argued that not all older unmarried women were in the same position. And the results 
of the investigation instigated by the council only added to this fragmentation of the image of older unmarried women. The report titled "The Unmarried Woman" ("De Ongehuwde Vrouw"), which was published in 1970, studied the living conditions of unmarried women aged between forty and sixty-five and compared them with the situation of unmarried men in the same age group. ${ }^{27}$ For both groups, the balance between workload and coping ability was examined. The first part of the report, focusing attention entirely on unmarried women, brought out significant differences within this group. According to the authors, the unmarried women who had been studied had very little in common except their marital status. Within the total group of more than 160,000 women in 1967 , a distinction should, therefore, be made between unmarried women in employment (67.3 percent), unmarried women who had left employment (20.4 percent), and unmarried women who had never had a job (12.3 percent) ${ }^{28}$ The groups with problems were the latter category, almost the entire middle category, and some of the women with jobs. Incidentally, two-thirds of the latter group considered it unfair that men and women had the same pensionable age. ${ }^{29}$ Some of the unmarried men also had problems; double or even triple demands were made on just under onefifth of the unmarried men. On the other hand, more than half of the older unmarried women had this problem. For this reason, the researchers considered the workload of unmarried women essentially incommensurable with that of unmarried men, but with regard to coping ability, the situation was a little more complicated.

The idea that older unmarried women should not all be lumped together, which was connected with the legal nature of the welfare state, changed the debate significantly. At the same time, another development also came into play. During a hearing organized by the Social Economic Council in preparation for its report, several of the women's organizations that had been invited-this did not include the Women's Action Committee — had already indicated that they rejected a lower pensionable age because men and women were equal and should therefore have equal rights and responsibilities. ${ }^{30}$ It was this argument, in particular, which would lead to a change in the opinions of the religious parties and the Dutch Labour Party, which had at first been relatively favorable toward a reduction of the retirement age, at the time of the reawakening of the women's movement. In 1967, a socialist member of Parliament was still troubled by this problem, as she stated,

On the one hand, one cannot ask for equal rights all the time, while one is at the same time pleading for special treatment, but on the other hand, we must bear in mind that women who are now about fifty, have never known equality. They have been discriminated in all respects ... [and] have always been looked upon as pitiable creatures, who did not really belong in paid employment, but in a family, and who had had the misfortune never to have married. ${ }^{31}$

But a year later, the same member of Parliament argued that she would no longer oppose rejection by the minister, in view of the possible discrimination of women. ${ }^{32}$ This meant that this Labour Party member, and many others, put older unmarried women on a par with women in general.

In the following years, both the fragmentation of the image of older unmarried women and the argument of equality, which caused older unmarried women, as it were, to melt into the general category of women, turned out to have a tremendous impact. Although trade unions, women's organizations, interest groups, and members 
of Parliament continued to discuss arrangements for older unmarried women until the late 1980s, an interdepartmental working party stated in 1973 that it was no longer willing to consider special arrangements for unmarried women, and the minister responsible followed suit in 1977. They argued that not all unmarried women had problems and that there were others who also had double jobs, such as single parents. ${ }^{33}$ Furthermore, the minister was of the opinion that a reduction of the retirement age would be incompatible with the principle of equality between men and women. ${ }^{34}$

A year later, this argument would be supported by a European directive, for on December 19, 1978, the European Community adopted the so-called third directive in which it was laid down that the principle of equality between men and women would also have to be implemented in the area of social security within a number of years. ${ }^{35}$ This did not mean that the debate about provisions for unmarried workers was closed, however, but a different pensionable age for unmarried women was no longer a possibility: older unmarried women were no longer viewed as a separate category in this context.

\section{CONCLUSION}

In the parliamentary debate about their pensionable age, older unmarried women were finally compared with a category-older unmarried men-that hardly played a part in the descriptions that the women themselves had given of their lives in their letters to the committee and in the answers to the committee's questionnaire. The older unmarried women described themselves as "exhausted" and "overburdened." In the committee's presentation to the public, older unmarried women were, however, mainly portrayed as women who were "treated unfairly." After years of discussion, this unfair treatment was contested in the parliamentary debate, and older unmarried women disappeared from sight.

Their fate, however, cannot be explained by the fact that these women only made up a relatively small category. This becomes clear upon comparison with other countries. In the second half of the 1930s, as Pat Thane and others have shown, the National Spinsters Association led the same kind of campaign in Great Britain as the Women's Action Committee did in the Netherlands. The English "Spinsters" also demanded a lower pensionable age; they wanted a reduction from sixty-five to fifty-five. They, too, enforced their demand by comparing their position with that of widows. Furthermore, they pointed out that it became increasingly difficult for unmarried women in their mid-fifties to hold down a job or to find a new position because employers regarded them as less efficient, less adaptable, and physically less attractive. According to the committee that investigated the matter, it was indeed somewhat harder for women from the age of fifty-five to hold or regain employment than for younger women or for men of the same age. But the committee considered the comparison between unmarried women and widows inappropriate; widows received a pension because of their widowhood, not because they grew "old" at the age of fifty-five. According to the committee, there was a case for a lower pensionable age for all women, however.

The British government adopted this idea partly because it could solve a problem of an entirely different nature: the common problem of the financial difficulties of husbands who turned sixty-five while their wives had not yet reached this age. In such cases, the couple would have to live on one pension. It was partly in view of this issue that the government announced in 1940 that the pensionable age for all women would 
be lowered to sixty. In this way, not all couples were helped out and the Spinsters' demand was only partly satisfied. Nevertheless, this measure killed two birds with one stone. ${ }^{36}$

In the 1980s, the Women's Action Committee in the Netherlands would not succeed in achieving what the Spinsters achieved in Great Britain forty years earlier, notwithstanding similarities with respect to the social category concerned and the campaigning style involved. Unlike the Dutch government, the English authorities had more reasons for the measure in question than just meeting the wishes of older unmarried women. But another important difference also played a part: the resistance to the unequal treatment of men and women was not as strong in England in the 1940s as it was in the Netherlands in the 1970s and 1980s.

The self-images of the women who had written letters to the committee and answered its questionnaire should certainly not be considered representative of the group of older unmarried women in general in that period. There is insufficient reason for assuming that the majority of older unmarried women considered themselves burnt out. In a sense, this was even belied by the behavior of the members of the committee, with all their activities and protest marches. Besides, those who reacted in this context were mainly women who were longing for an early retirement and apparently wanted to give up work.

However, we did not intend to reconstruct a representative self-image of older unmarried women. What we are interested in is the contrast between the picture that the women in question drew of their situations and the image of these women that was projected by the committee. This contrast was partly due to the legal nature of the welfare state and the game of comparison that this entailed. The shifts in the parliamentary image are also easier to understand in the context of the welfare state. This image shifted because the differences and similarities that were brought forward by those in favor of a lower pensionable age were denied and parried with new similarities and differences by opponents of the idea. But the most important shift took place at the conclusion of the debate. While the older unmarried women wanted to bring their situation into the picture, the opposite happened in the course of the parliamentary debate. Due to fragmentation of the category of older unmarried women and equalization of this category to women in general, older unmarried women did not get into the picture, but were left out instead.

\section{NOTES}

1. International Center for Information and Archives of the Women Movement (Internationaal Informatiecentrum en Archief voor de Vrouwenbeweging; hereafter, IIAV), Archives Women's Action Committee for Early State Pensions (AVA), letter W. Guis, October 5, 1969. We would like to thank Marijke van der Horst for her translations of the original Dutch quotations.

2. The notion of self-image also refers to the attribution of characteristics to oneself and the evaluation of those characteristics, but this is not at stake here.

3. D. G. Troyansky, "Old Age, Retirement, and the Social Contract in 18th- and 19th Century France," in Toward a Cultural History of Aging, ed. C. Conrad and H. J. von Kondratowitz (Berlin, Germany: Deutsches Zentrum für Altersfragen, 1993).

4. Many of these descriptions, in letters and answers to the questionnaire, have been given in custody to the IIAV; the other descriptions are still part of the private archives (PA) of one of the members of the committee, M. van Saane. 
5. Archives Second Chamber of Parliament (Archief Tweede Kamer; hereafter ATK), letter Women's Action Committee for Early State Pensions to Members of Parliament July 14, 1966, appendix "Report of Questionnaire" ("Verslag van de enquete"). According to this report, out of more than 1,000 questionnaires distributed, 758 were completed and returned to the committee. Out of these 758 questionnaires, 750 are still preserved at the IIAV.

6. In all, we found 116 letters and postcards in the archives. Letters from institutions, as well as from the president and secretary of the committee, were not relevant to our research questions. The same holds for the 19 letters of divorced, widowed, and married women. Other letters were left out of the project because they did not include biographical information. Such letters concerned, for instance, short notifications of adhesion and requests for information or were intended to send apologies for absence.

7. Of more than one-half of these thirty-nine letters and postcards, we were absolutely sure that they were written by unmarried women; this was clear from their content and sender"Miss" ("Mejuffrouw"). Two-thirds of the thirty-nine letters clearly came from elderly women. Letters in which senders did not mention their age, did not use a husband's name, and did not classify themselves in another category than the one of unmarried women were considered to be letters of elderly unmarried women. Four women wrote more than one letter, and some letters were signed by more than one woman. We decided to define elderly women as women being forty and older because the committee stated that women should take it more easy during and after menopause. The way in which elderly unmarried women compared their supposed rights with those of widowed women of forty years and older was another important consideration. The committee itself, however, only analyzed the questionnaires completed by women between fifty and sixty-five.

8. Out of the 750 questionnaires found in the archives, 541 were completed by unmarried women, 189 by divorced women, 15 by widowed women, and 5 by married women. Four of the 241 relevant questionnaires did not mention the sender's age. Of the remaining forms, 25 were completed by women aged between forty and up to and including fifty. All other forms came from women older than fifty, the oldest of them being seventy-two.

9. We used the following codes. The figures in parentheses after the codes refer to the amount of times this remark was made: $\mathrm{vgw}=$ not being treated righteously compared to widows (27); $\operatorname{vgm}=$ not being treated righteously compared to (unmarried) men (8); $\operatorname{vgx}=$ not being treated righteously compared to remaining others (47); lgw = worked long enough (29); gzh = complaints about health (37); zbp = difficulty of job (48); fys = complaints about physical condition (being "tired," and so on) (38); zdt = difficulty of double job (paid job, domestic labor) (67); $\mathrm{zmt}=$ difficulty of triple job (paid job, domestic labor, care) (8); ong = not being taken seriously because of being unmarried (7); ink = complaints about income (26); remaining remarks (25). Total remarks is 367 .

10. The above quotations come from, respectively, PA M. van Saane, letter T. Veenstra March 5, 1973; ibid., letter T. T. Smith March 10, 1971; IIAV, AVA, questionnaire (q), no. 266; ibid., q-447; ibid., q-483; PA M. van Saane, letter J. M. Mets December 20, 1971; IIAV, AVA, q-740; ibid., q-496; ibid., q-171; ibid., q-609; ibid., q-538; ibid., q-692; ibid., box 1, letter J. van Heumen April 8, 1969; ibid., box 1, letter ... Schatorje, not dated; ibid., box 1, letter G. Groet, January 18, 1970.

11. IIAV, AVA, reprint of W.Cr.-d.V., "Koek en ijzer,” Patrimonium, November 18, 1966.

12. Interview M. van Saane, Amsterdam June 12, 1991; PA M. van Saane, letter I.J.A. Oosterbaan to Emmy van Overeem March 18, 1974.

13. ATK, Letter Women's Action Committee for Early State Pensions to Members of Parliament July 14, 1966, with appendices (hereafter abbreviated as: letter July 14, 1966), p. 7. See also p. 8 and p. 13; IIAV, AVA, "Criticism of Advice of Social Economic Council of October 21, 1966 concerning reduction of retirement age for unmarried women with respect to the General Old Age Pensions Act. July 1967” ("Het SER advies d.d. 21 oktober 1966 inzake verlaging pen- 
sioengerechtigde leeftijd voor de ongehuwde vrouw in de AOW, critisch bezien. Juli 1967”) (hereafter abbreviated as Criticism of Advice of Social Economic Council 1966), p. 1.

14. ATK, letter July 14, 1966, p. 11. For comparison with widows, see also PA M. van Saane, "Widows and Emancipation" ("Weduwen en emancipatie") [fall 1974].

15. Next to this, the committee sometimes spoke about a (partial) abolishment of Widows Act contributions for unmarried women and recommended a reduction of the retirement age for men from sixty-five to sixty. In the latter case, however, the retirement age for women should be reduced to fifty-five. ATK, letter July 14, 1966, p. 5.

16. IIAV, AVA, "The Privileging of the Married Woman in the Netherlands" ("De bevoorrechting van de gehuwde vrouw in Nederland"), September 1973.

17. ATK, letter July 14, 1966, pp. 16, 9, 19. See also PA M. van Saane, letter Women's Action Committee for Early State Pensions to H. Verwey-Jonker April 6, 1967; IIAV, AVA, Criticism of Advice of Social Economic Council 1966, pp. 20-24, 45-46; PA M. van Saane, letter Women's Action Committee for Early State Pensions to Members of Parliament, October 23, 1967, p. 2.

18. ATK, letter July 14, 1966, p. 8.

19. ATK, letter July 14, 1966, p. 4, see also p. 10; IIAV, AVA, Criticism of Advice of Social Economic Council 1966, p. 5.

20. IIAV, AVA, Criticism of Advice of Social Economic Council 1966, p. 12.

21. C.J.M. Schuyt, "De fragmentering van bestuur en beleid in de verzorgingsstaat," in Boekaflevering Mens en Maatschappij (Deventer, the Netherlands: Van Loghum Slaterus, 1979); C.J.M. Schuyt, "Het rechtskarakter van de verzorgingsstaat," in De stagnerende verzorgingsstaat, ed J.A.A. van Doorn and C.J.M. Schuyt (Meppel/Amsterdam: Boom, 1978). Both articles were also published in C.J.M. Schuyt, Tussen macht en moraal. Over de plaats van het recht in de verzorgingsstaat en de democratie (Alphen aan de Rijn/Brussels: Samson, 1983).

22. However, this does not mean that the issue of the retirement age of men and women within other pension schemes had not been discussed on the national level earlier.

23. Record of Parliament (Handelingen der Staten-Generaal) IIB 1955-56 4900, no. 6 (VV) 8; IIB 1960-61 6100 H XII no. 13 (VV) 9, no. 15 (MVA) 17; II 1960-61 3700, 3714-15; I 19601961 3352; IIB 1961-62 6540 no. 3 (MVT) 5-6, no. 5 (VV) 1-2, no. 9 (VMO) 2; II 1961-62 3791, 3793-95, 3798-99, 3808; IB 1961-62 6540 no. 132 (EV) 1; IIB 1964-65 7762 no. 5 (VV) 4; II 1964-65 364; II 1964-65 395, 398.

24. Tijdschrift voor Ziekenverpleging 21 (1968): 387.

25. For this and other denials, see Record of Parliament IIB 1955-56 no. 7 (MVA) 8; IB 1960-61 6100 H XII no. 90a (MVA) 10.

26. Sociaal-Economische Raad, Advies inzake verlaging van de pensioengerechtigde leeftijd voor de ongehuwde vrouw in de algemene ouderdomswet (The Hague: Staatsuitgeverij, 1966). For other objections of the Social Economic Council against reduction of the retirement age of unmarried women, see Sociaal-Economische Raad, Advies inzake de positie van de gehuwden en de ongehuwden in de sociale verzekering (The Hague: Staatsuitgeverij, 1963).

27. De Ongehuwde Vrouw. Onderzoek naar de levensomstandigheden van de ongehuwde vrouwen van 40 tot 65 jaar (Nijmegen, the Netherlands: Instituut voor Toegepast Sociologie, 1970). A summary was published in Record of Parliament, IIB 1970-71 11074.

28. Ibid., 5-6.

29. Ibid., 11.

30. Archives Social Economic Council, no. SV/266, Proceedings of the 72nd meeting of the Committee of Social Insurances, March 11, 1966, The Hague (Verslag van de tweeënzeventigste vergadering van de Commissie Sociale Verzekeringen, gehouden op 11 maart 1966 te 's-Gravenhage).

31. Record of Parliament II 1967-68 S9.

32. Record of Parliament II 1968-69 T34. Moreover, this would mean a loss of benefits for those women who could claim an allowance on grounds of the Disablement Insurance Act, which they would lose when retiring. 
33. Record of Parliament IIB 1972-73 12330.

34. Letter of January 18, 1977, to President of Second Chamber of Parliament. Staatscourant January, 20, 1977, no. 14.

35. E. V. Knopper, "Gelijke behandeling in de AOW," in Gelijke behandeling van vrouw en man ten aanzien van pensioenen, ed. W. M. Levelt-Overmars (Deventer, the Netherlands: Kluwer, 1988), 13.

36. P. Thane, "Een onvermoeibare levenslust. Beeld en zelfbeeld van oude vrouwen in Engeland," in Lange levens, stille getuigen. Oudere vrouwen in het verleden, ed. M. Stavenuiter, K. Bijsterveld, and S. Jansens (Zutphen, the Netherlands: Walburg, 1995); J. Roebuck, "When Does Old Age Begin? The Evolution of the English Definition," Journal of Social History 12 (1979): 416-28; J. Roebuck and J. Slaughter, "Ladies and Pensioners: Stereotypes and Public Policy Affecting Old Women in England 1880-1940," Journal of Social History 13 (1979): 105-14. 